\title{
〔原著論文〕
}

\section{形状記憶合金アクチュエータの 剛性制御に関する研究}

\author{
佐川浩文* 橋本稳**佐藤公子**
}

この論文には，形状記憶合金を用いたアクチュエータの剛性制御の一方式が提案されている．このアクチュエ ータは，拮抗する一対の形状記憶合金線によって構成され，線は直接通電法によって加熱される．アクチュエー タの静的モデルを考案し、このモデルから，線流す電流の総量により，剛性制御が可能なことを見出した．制 御方式の妥当性は，実験によって確められた。なお，剛性を調整しながらの位置制御の方式をる，提案されてい る.

\section{1. 緒言}

エレクトロニクスの進展により制御系の構成が比較的 容易であることなどの理由より，昨今，ロボット用アク チュエータとして電気式が最も多く使われている. しか し，この種のアクチニエータはそれ自身で関節の剛性を 調整する機能がなく，いわば柔軟性に欠ける。そのため コンプライアンスを要する柔軟な動作をさせるのに，位 置と力のハイブリッド制御や位置サーボ剖性による制御

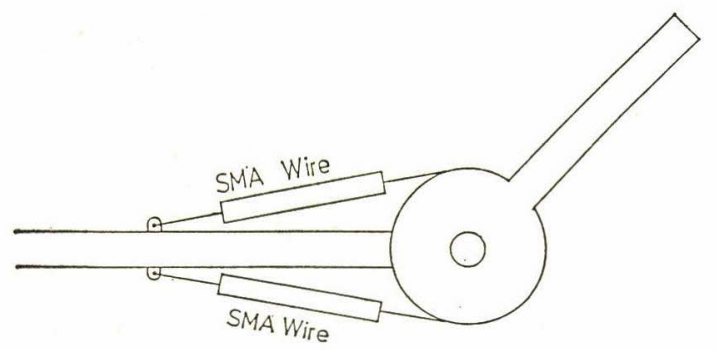

Fig. 1 Schematic structures of the SMA actuators. Actuator with two SMA wires

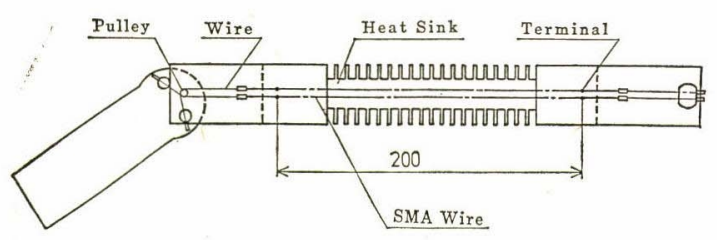

Fig. 2 Structural drawing of the SMA actuator

原稿受付 1987 年 3 月 31 日

* 三菱電機株式会社

$* *$ 電気通信大学
などのようにソフト的に行なったりり，あるいはリモー ト・センタコンプライアンス $(\mathrm{RCC})$ などのように受動 的なバネ要素といら特殊な装置を採用している2).

一方, 筋はそれ自身が㷒性を可变し得るバネのように なって互いに拮抗されており, アクチュエータ自身に岡 性を調整し得る機能を備えている3). この機能はコンプ ライアンスを要する柔軟な動作に適したものとなってい る.こういったアクチュエータが開発されれば, 柔軟性 のある動作が容易に行なわれるであるら。そこで筆者ら はこのアクチュエータを開発するのに, 温度により筋の ように収縮, 弛緩でき剛性を可変し得る形状記憶合金 ${ }^{4)}$ （以下 SMA と略記する）が有效であると考えた。

これまで, SMA のサーボアクチュエータへの応用に 関する研究は，位置制御のための SMA アクチュエー タのモデル化に関するもの5), SMA をアクチュエータ としてのみならず位置センサとしても使用して位置制御 を行ら研究印, 出力が变位㳖存しないような機構の提 案わなどが行われてきた。これらは、アクチュエータの

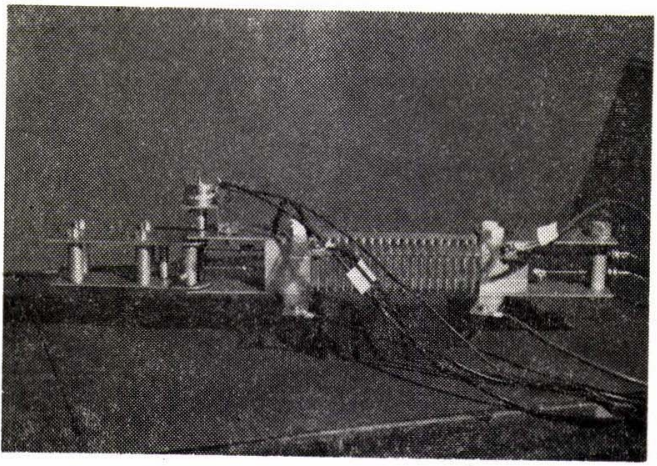

Fig. 3 Picture of the SMA actuator 
変位または出力に関する研究で, アクチュエータの剛性 を扱ったものはない，本アクチュエータにおいても位眉 のサーボ用性を利用することによってその剛性を変える ことが出来るものと思われが，SMA の材料特性を利用 して剛性を制御するところに本研究の特徽がある.

本研究は，このSMA を用いて前述の機能を備えた柔 軟性のあるアクチュエータを開発することを目的とした ものである.

\section{SMA アクチュエータのメカニズム}

Fig. 1 は試作した SMA アクチュエータの楼成図で ある.これは 2 本の SMA 線を同時拮抗させた構造で 人間のものと形式的に同等なモデルをしている.この SMA 線の剛性を適当に変えることで拈抗させる度合い を変え，関節の剛性を調整しょうというものである.

Fig. 2 は試作した SMA アクチュエータの概略図で, 外観を Fig. 3 に示す. 関節にはポテンショメータを㘧 り付けてあり，角度の検出を行なう. 使用した SMA 線 は $\phi 1.0 \mathrm{~mm}$ の $\mathrm{Ti}-\mathrm{Ni}$ 線 (Ni : 49.6at\%) で有効長 さ（加熱する部分の長さ）を $200 \mathrm{~mm}$ とした. SMA 線 は使用初期における形状回復の繰り返しによる伸びをな
くすために，形状記憶熱処理後，負荷をかけて熱サイク ルを 100 回ほど繰り返した. しかしこの処理により SMA 線は二方向形状記憶効果4)を示すようになり, 後 述するが 2 本の SMA 線の拮抗状態をくずすものとなる. SMA 線は $\phi 1.0 \mathrm{~mm}$ のステンレスワイヤーを結合さ せプーリに介した. このプーリの半径は $6.1 \mathrm{~mm}$ であ る. ここで, 関節の剛性の可変できる範囲は, SMA 線 の長さ及びプーリの径によって変えることが出来る.

SMA 線の加熱は直接通電させることで行ない，通電 方法はパルス幅変調 (PWM) 法とし, 最大通電量を $20 \mathrm{~A}$ とした. また，冷却については送風を伴ったヒー トシンク方式）を採用し，ヒートシンクはアルミニウム 製のフィンである.

\section{3. 力学モテル}

この SMA アクチュエータをロボットに応用するのに まずその力学モデルを明らかにしなければならない，本 章はこれについて述べる.

SMA 線は温度によりその棡性が変化する. その発生 力と変位の関係を Fig. 4 の（a）のように近似して考 える. 2 本の SMA 線を同四の (b) のような拮抗させ

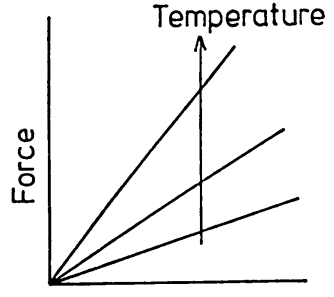

Displacement

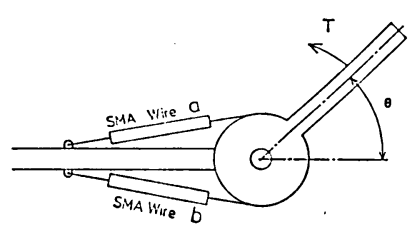

(b) Schematic drawing of the actuator. (a) Relationship between the force and the displace ment of SMA wire.

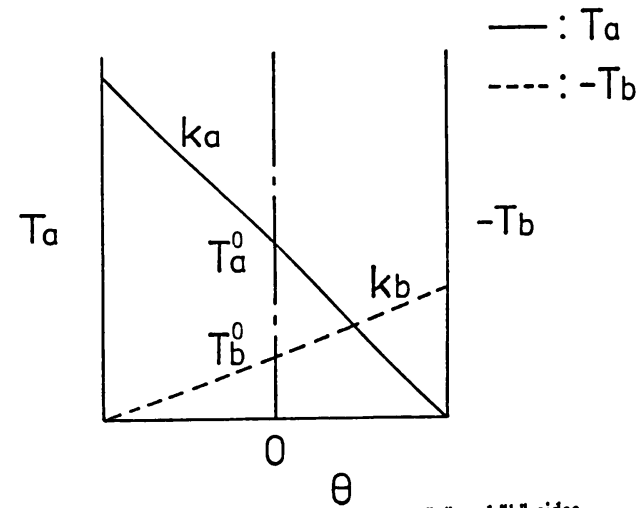

(c) Torque and angle relationships on the " $\mathrm{a}$ " and " $\mathrm{b}$ " sides.

Fig. 4 Static model of the SMA actuator

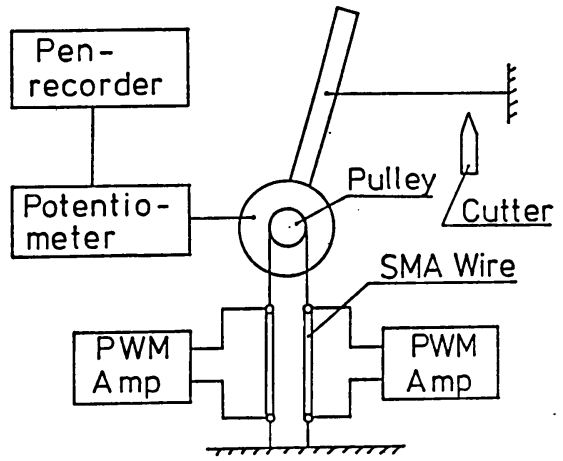

(a) Schematic drawing of the experimental system.

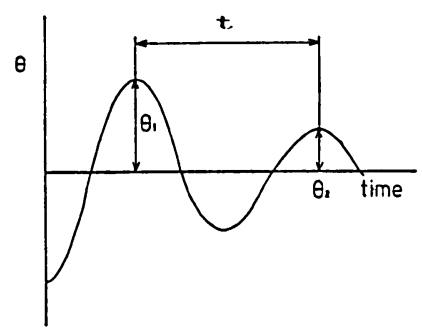

(b) Response of the system.

Fig. 5 Measurement of stiffness by the free vibration experiment. 
たアクチュエータとして構成すれば, $\mathrm{a}, \mathrm{b}$ 側のトルク $T_{a}, T_{b}$ とリンク角 $\theta$ との関係は同四の（c）のように なり，それぞれ次のように表わされる゙).

$$
\begin{aligned}
& T_{a}=T_{a}{ }^{0}-k_{a} \theta \\
& -T_{b}=T_{b}{ }^{0}+k_{b} \theta
\end{aligned}
$$

ここで, $k_{a}, k_{b}$ は $\mathrm{a}, \mathrm{b}$ 側の剛珄, $T_{a^{0}}, T_{b}{ }^{0}$ は $\theta=0$ [ $\left.\mathrm{rad}\right]$ でのトルクである. そうすると, アクチュェータ全体の トルク $T$ は上記の 2 式の差をとって次のようになる.

$$
\begin{aligned}
T & =T_{a}-\left(-T_{b}\right) \\
& =T_{a}{ }^{0}-T_{b}{ }^{0}-\left(k_{a}+k_{b}\right) \theta
\end{aligned}
$$

$\left(k_{a}+k_{b}\right)$ がアクチュエータの剛性で, 2 本の SMA 線の 剛性の和のみで決まる. 式 (3.3) が本研究の SMA ア クチュエータの力学特性だが，これは温度に依存するも のであり加熱されると発生力と剛性が変化する.つまり $T_{a}, T_{b}$ 及び $k_{a}, k_{b}$ は温度によって表わされるものと考 えられる.ところで, SMA 線の加熱は直接通電により 行ならことから，式 (3.3) を PWM 通電による通電 量デューティ比（０から1の值をとる）として表わせば よいと考える. 次に, この式をデューティ比でモデル化 することを検討する.

まず, 剛性とデューティ比のモデル化について述べる. 前述したよらにアクチュエータの剛性は 2 本の SMA 線 の剛性の和によって決まることからデューティ比の和で モデル化することを考える. Fig. 5 はそのための実験 概略図である. Fig. 5 (b) において， $\theta_{1} ， \theta_{2}$ はそれぞ れ一番目と二番目の振動の振幅で, $t$ はその周期である 2 本の SMA 線を同時に PWM 通電し拮抗させ, リン クを静止した状態から $0.3 \mathrm{rad}$ 程度の初期变位を与える. それからカッターによりリンクを瞬間的に支持部から離 し自由振動させる. その応答から剛性を測定した. 自由 振動の運動方程式は

$: d=0.0$ [duty]

$\therefore: d=0.4$

$\Delta: d=0.8$

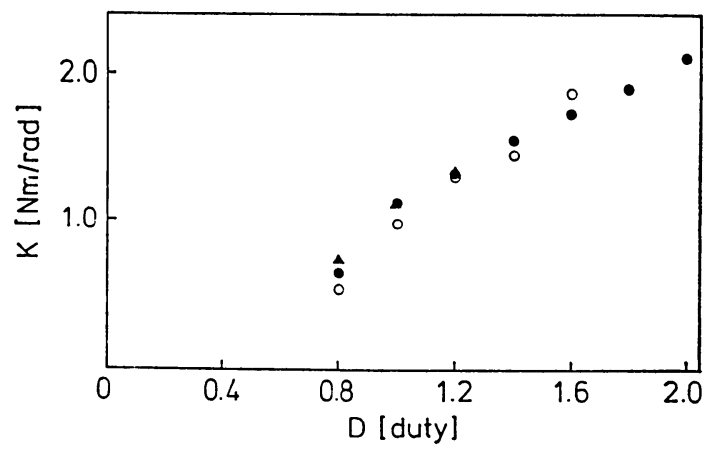

Fig. 7 Relationship between the stiffness and the sum of duty ratios
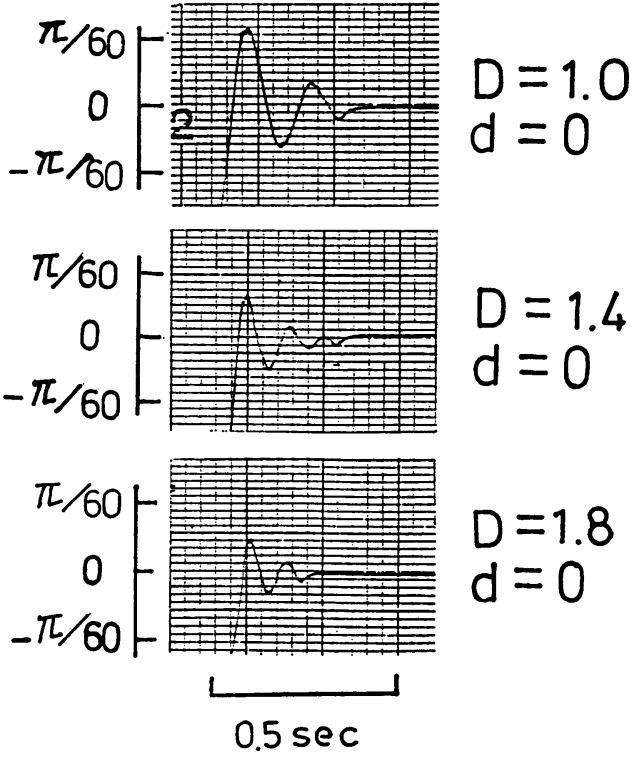

Fig. 6 Experimental results of free vibration

$$
J \ddot{\theta}+c \dot{\theta}+K \theta=0
$$

と表すことが出来る. ここで，Jは慣性モーメント， $c$ は粘性係数, $K$ が剛性である.これより用性は次式に よって算出することが出来る.

$$
K=\left(4 \pi^{2}+\lambda^{2}\right) J / t^{2}
$$

ここで， $\lambda=1 \mathrm{n}\left(\theta_{1} / \theta_{2}\right)$ である. ここでは系を線形 1 自 由度として, 自由振動実験で得た剛性と静的な剛性が一 致すると仮定して剛性を振動実験から測定した．応答は ポテンショメータからペンレューダに検出した. なおア クチュエータは水平面上に設置してある. Fig.6はその 測定結果の一例である. $D$ は $a, b$ 側の デューティ比 $d_{a}, d_{b}$ の和で $D=d_{a}+d_{b}, d$ はその差で $d=d_{a}-d_{b}$ で

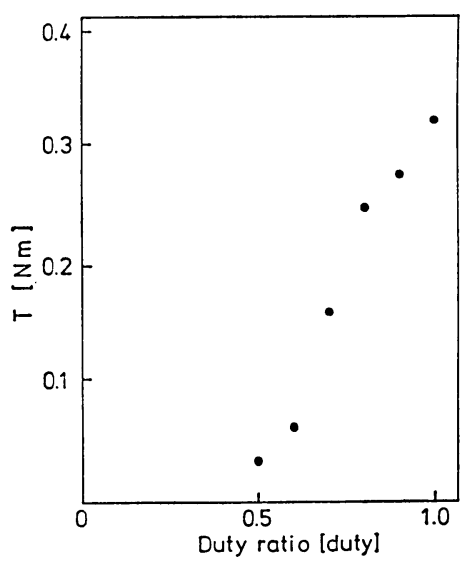

Fig. 8 Relationship between the torque and the duty ratio 
ある. $D$ の増加に伴って振動周期 $\boldsymbol{t}$ が短くなっており， 剛性が変化していることが分かる.これらの測定結果か ら㓮性を（3.5）式を使って計算した結果を Fig. 7 に

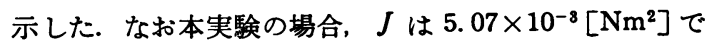
ある. 印は $d か ゙ 0.0$ ， 印は $0.4 ， \Delta$ 印は 0.8 であ り,この結果よりデューティ比の差によって若干の相違 があるが, 用性 $K\left(=k_{a}+k_{b}\right)$ はデューティ比の和 $D$ のみで決まり，それらはは湶形関係にあることがわか る. 従って次のよらにモデル化する.

$$
K=\beta\left(D-D_{0}\right)
$$

ただし， $\beta, D_{0}$ は定数である.ここで $D$ があまり小さい と 2 本の SMA 線のきっこう状態がずれ，二方向形状 記憶効果のためにたるみを生じる、いま $D^{\prime}$ をっっう 状態を維持する最小の值とすると，一般に $D^{\prime}$ は $D_{0}$ よ りも大きく，実質的な上式の適用範囲は $D>D^{\prime}$ である。 な拉本実験は一定の冷却条件及び一定外部負荷のもとで 行ったもので，実際の使用条件のもとでは長時間使用に よるヒートシンクの温度上昇や外部負荷の変動が考えら れ、これらにより同じ $D$ であってもアクチュエータの 剛性が変化するものと考えられる. また，SMA の相変 態に基ずくヒステリシスにより昇温過程と降温過程では 剛性が若干異なる. しかし, 本モデルでは第一次近似と してこれらの効果を無視している.

次に $\theta=0[\mathrm{rad}]$ での基準トルク $T_{a}{ }^{0}, T_{b}{ }^{0}$ のモデル 化について検討する. Fig. 8 は一方の SMA 線のトル クとデューティ比との関係を調べたすのである. トルク はロードセルより測定した．これより基準トルクとデュ ーティ比は線形近似して次のよらに表わすことにする.

$$
\begin{aligned}
& T_{a}{ }^{0}=\alpha_{a}\left(d_{a}-d_{a 0}\right) \\
& T_{b}{ }^{0}=\alpha_{b}\left(d_{b}-d_{b 0}\right)
\end{aligned}
$$

ここで, $\alpha_{a}, \alpha_{b}$ は比例定数で $d_{a 0}, d_{b 0}$ はオフセット量

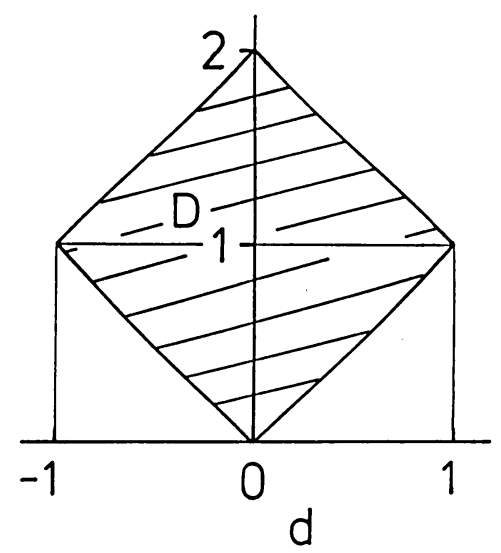

Fig. 9 Relationship between the " $D$ " and the " $d$ "
である. a, b 側の SMA 線は寸法, 組成など同等なる のを使用するため，それぞれの定数については，

$$
\alpha_{a}=\alpha_{b}=\alpha, d_{a 0}=d_{b 0}=d_{0}
$$

が成立するものと考え，式（3.7)，（3.8）を書き改的る と,

$$
\begin{aligned}
& T_{a}{ }^{0}=\alpha\left(d_{a}-d_{0}\right) \\
& T_{b}{ }^{0}=\alpha\left(d_{b}-d_{0}\right)
\end{aligned}
$$

となる.

さて，以上でそれぞれのパラメータをモデル化したわ けたが，それらを式（3.3）に代入し SMA アクチュエ ータの力学モデルを表わすと次のよらになる。

$$
T=\alpha d-\beta\left(D-D_{0}\right) \theta
$$

定数はそれぞれ

$\alpha=0.95[\mathrm{Nm} /$ duty $], \beta=0.90[\mathrm{Nm} / \mathrm{rad} \cdot \mathrm{duty}]$ $D_{0}=-0.2$ [duty]

である.

\section{4. カ学モデルの妥当性}

前節でSMA アクチュエータの力学モデルが式 (3.12) で表わされると述べた．ここではその妥当性について調 ベる. 力学モデルからわかるように $D$ によって関節の 剛性を可変でき，その剛性において即ち $D$ が一定のも とで， $d$ を変えることにより角度を可変し得る. 実験は 力学モデルに従い, 目標とする角度と剛性を直接オープ ンに指令することで行なった.

ここで注意すべきことがある， $d_{a}, d_{b}, d, D$ はそれ ぞれ

$$
\left.\begin{array}{rl}
0 \leqq d_{a} \leqq 1, & 0 \leqq d_{b} \leqq 1 \\
-1 \leqq d \leqq 1, & 0 \leqq D \leqq 2
\end{array}\right\}
$$

の範囲の値をとる. $d_{a}=(D+d) / 2, d_{b}=(D-d) / 2$ で あるから、

$$
-d \leqq D \leqq 2-d, d \leqq D \leqq 2+d
$$

であり， $D$ と $d$ のとる領域は Fig. 9 の斜線部分であ る. このことは $d$ の值によって $D$ のとるべき領域が限 られてしまうことで，換言すれば，角度によって剛性の 变えられる範囲が限定され, 角度が 0 [ rad $]$ よりも遠 いところでは剛性のとれる領域が狭くなることである.

このように角度と剛性の決め方にはそのとるべき領域を 考慮しなくてはならない。

Fig. 10 は実験結果を示したものである. 平衡角度は, $-\pi / 6,-\pi / 12,0, \pi / 12, \pi / 6[\mathrm{rad}]$ でそれぞれにおい $\tau$, 剛性の目標値 $\bar{K}$ を $0.9,1.1,1.3,1.5[\mathrm{Nm} / \mathrm{rad}]$ とした. これらの角度と剛性の値を目標値として， 3 章 で示したモデルにしたがって $d$ と $D$ の值を求め, これ らを与える $d_{a}, d_{b}$ をそれぞれの SMA 線に入力した. そしてその場合のアクチュエータの平衡位置及び剛性を 


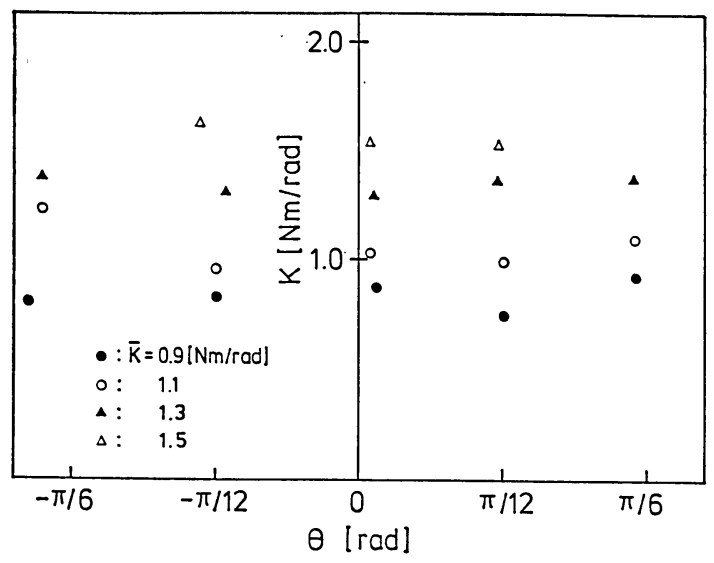

Fig. 10 Validity of the static model

それぞれポテンショメータと 3 章で述べた自由振動法に より測定した.なお， $-\pi / 6, \pi / 6[\mathrm{rad}]$ につてては用性 が $1.5[\mathrm{Nm} / \mathrm{rad}]$ の場合, 領域外となる.この結果よ り目標值から若干のずれが生じているが，それぞれの角 度において目標とする剛性を得ることができ，式 (3.12) のモデルが妥当なものであることがわかった.

\section{5. 伸張反射実験}

前節でSMA アクチュエータの力学モデルを示し, 関 節の剛性を 2 本の SMA 線に与えるデューティ比の和に よって変え得るものであることがわかった．ここでは， SMA 線の拮抗させる度合い即ち剛性が伸張反射にどん な影響を与えるか調べる。

\section{1 实験方法}

伸張反射とはこの場合 2 本の SMA 線を同時拈抗させ, 関節角を一定保持している状態で衝撃外乱を与えること である. Fig. 11 にその実験概略図を示す。アクチュエ 一夕を水平に設置し，PWM 通電により 2 本の SMA 線 を同時拮抗させリンクを定位置に保持する.この状態か らハンマーを自由落下して伸張反射を起こさせ, 関節角 の応答を測定した.

\section{2 結 果}

Fig. 12 に応答例を示す。 Dが大きいほどつまり剛性 が大きいほど外乱に対する影響が小さくなることがわか る.この応答を表わすパラメータとして衝撃が加わって からの最初の振動の振幅を $\theta_{1}$, 時間を $t_{1}$, 次の振動の 振幅を $\theta_{2}$ とし、それらのパラメータと $D$ との関係を Fig. 13 に示す. $\theta_{1}$ が小さいということは衝撃に対する 力が強いといえ， $t_{1}$ が小さいことは振動周波数が高いこ とに相当し， $\theta_{2} / \theta_{1}$ が小さいことは減衰性が良い。これ らはDが大きくなるにつれ減少する傾向を示し, 衝撃外 乱に対して良好なるのとなる．位置制御の観点から換言

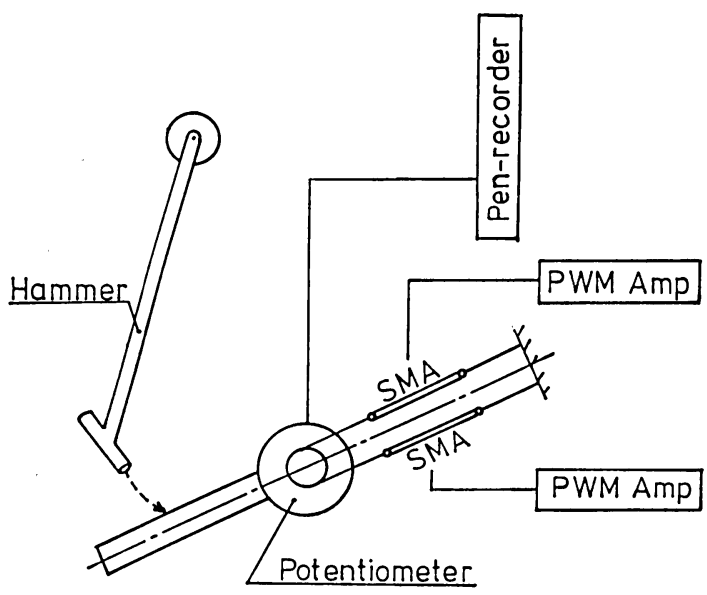

Fig. 11 Schematic drawing of the experimental system for elongating reflex

すると，制御において良好となり得るままた，減衰性が 良くなることから SMA アクチュエータは剛性（弾性要 素) のみでなく，粘性も含んでおり粘弾性要素と考えら れ、,10), それ自身が安定な系であると思われる.

ここで参考までに人間の时関節におけ化張反射と比 較してみよう. Fig. 14 にそれを示す. 文献 11)による と筋電位から筋の発生力を推定しており，Fは伸張反射 の際，元の位固に保持しょうとする力で関節の剛性の目 安となるものである、 A， B被験者の別を示している. この図と Fig. 13 を比較すると, それぞれ同様な傾向を 示しSMA アクチュエータは筋アクチュエータと同様な 特性をもっていると考兄られ，それ自身で粘弾性を可変
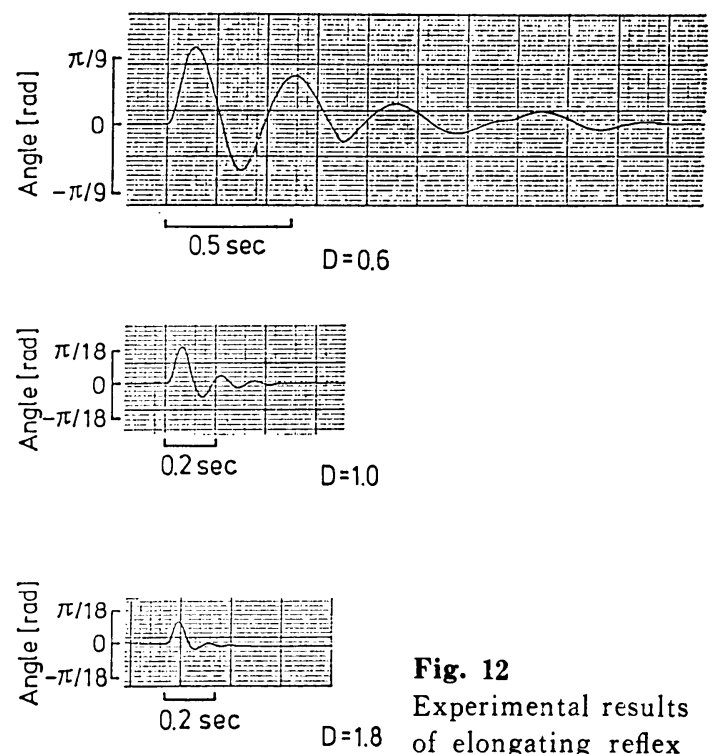

Fig. 12

Experimental results of elongating reflex 
得るといった電気式アクチュエータにない 優れた機能があると思われる.

\section{6. 㓮性及び位国の制御}

本章では㓮性と位置の制御について述べ る. 関節の剛性が 2 本の SMA 線のデュー

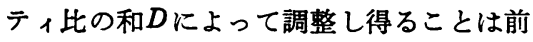
述したと拈りである.そこで，剛性の制御 はDを直接指令することで行ならことを考 える.これは正確に制御できないが，自己 の用性を調整し得るといった SMA アクチ ニエータの特徵を直接利用できる. 一方位 置については，外部負荷が一定の条件では デューティ此の差 $d$ を指令值としてオープ ンに制御することが出来るが，実際の使用 条件下では外部負荷の変動が考えられ，そ れにより位置の制御性は著しく影警され る. そこでこここでは位直に関してのみつ ィードバック制御を行い, 剛性については Dを指令值とする制御法について検討する.

\section{1 フィードハッック制御方式}

位置フィードハッック制御にはいろいろな方法が考兄
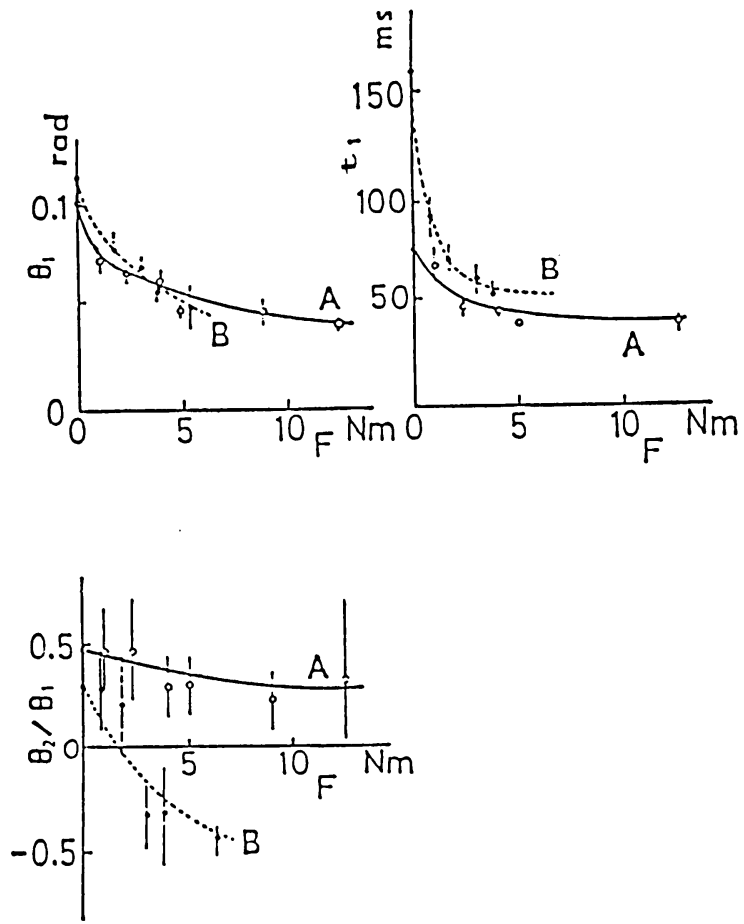

Fig. 14 Relationship between the response for elongating reflex and the tension for human
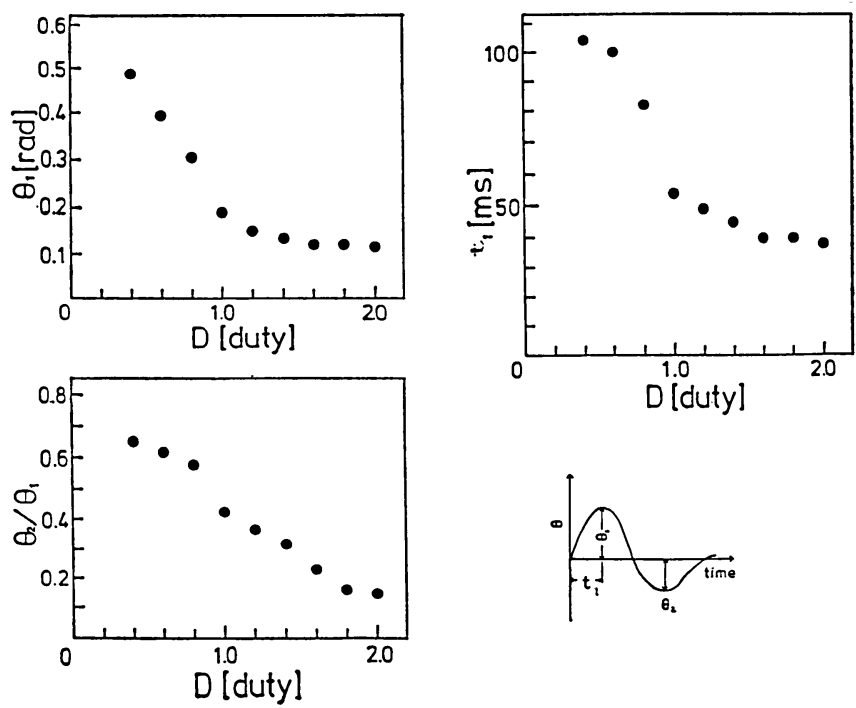

Fig. 13 Relationship between parameters of the elongating reflex response and the sum of duty ratios

られるが，前述の伸張反射実験よりアクチュエータ自身 が安定な系になることから，まず本研究では単純な比例 制御で行ならことを考えた. 以下これについて述べる.

いま，アクチュエータに外力が働かないとする. 平衡 状態より偏差が生じ，それぞれ

$$
\theta=\bar{\theta}+\Delta \theta, \quad T=\bar{T}+\Delta T
$$

とする. ただし， $\bar{\theta}, \bar{T}$ は平衡角度，平衡トルクで $\Delta \theta$, $\Delta T$ は偏差である. 力学モデルの式 (3.12) において, 操作量をd とすると $\bar{T}, \Delta T$ はそれぞれ次のようになる.

$$
\begin{aligned}
& \bar{T}=\alpha \bar{d}-\beta\left(D-D_{0}\right) \bar{\theta} \\
& \Delta T=\alpha \Delta d-\beta\left(D-D_{0}\right) \Delta \theta
\end{aligned}
$$

たたし， $\bar{d}$ は平衡操作量， $\Delta d$ は偏差に対する操作量で ある. $\bar{d}$ はこの場合 $\bar{T}=0$ より，

$$
\bar{d}=\frac{\beta\left(D-D_{0}\right)}{\alpha} \bar{\theta}
$$

となる. そして， $\Delta d$ を比例制御として次のように与え る.

$$
\Delta d=-k \Delta \theta
$$

たたし， $k$ は比例ゲインである. 実䟢に与える操作量 $d$ は

$$
\begin{aligned}
d & =\bar{d}+\Delta d \\
& =\frac{\beta\left(D-D_{0}\right)}{\alpha} \bar{\theta}-k \Delta \theta
\end{aligned}
$$

である. そうすると, 式 (6.3) は，

$$
\Delta T=-\left\{\alpha k+\beta\left(D-D_{0}\right)\right\} \Delta \theta
$$

となり, 系の剛性は $\left\{\alpha k+\beta\left(D-D_{0}\right)\right\} て ゙, \beta\left(D-D_{0}\right)$ はSMA 自身の剛性， $\alpha k$ は比例制御によるサーボ剛性 である.これより位置のフィードバックを伴った場合に 


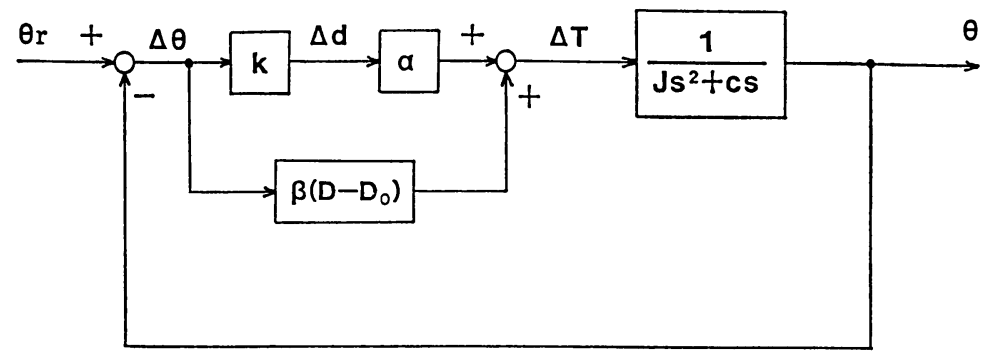

Fig. 15 Block diagram of po. sition control

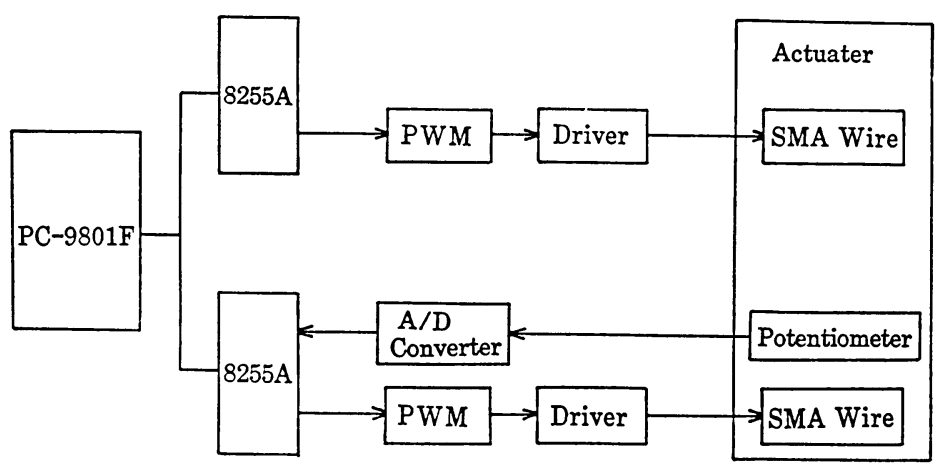

Fig. 16 Schematic drawing for the control system

でも，Dを指令值として関節の剛性を変えられることが 分かる. このときサーボ棡性は系全体の剛性におけるオ フセットとして働いている. 従って位固サーボの制御性 が，関節の剛性の変化に影響されないといら特徵を持っ ている. 以上の位置制御系をブロック線図で表わすと

Fig. 15 のよらになる.

\section{2 位䚓制御実験及び結果}

実験はいろいろな比例ゲイン $k$ において，目標角度を $0[\mathrm{rad}]$ から $\pi / 9[\mathrm{rad}]$ にステップ入力させることで行 なった. Fig. 16 はその制御回路図である.

Fig. 17 は, $k$ が 2.2, 6.6, 11 [duty/rad] のとき におけるステップ応答の結果を示したものである. $k$ を $11[\mathrm{duty} / \mathrm{rad}]$ より大きくしても応答に変化がみられな かった．また，速応性は $k$ を大きくすれば幾分よくなる が，この場合最大でも目標角度に達するまでの時間が約 2 秒かかりあまりよくない. しかし，オーバーシュート がなく，SMA 線を互いに拮抗させ単純な制御系で安定 性のある位圆制御ができた：これは前述の伸張反射実験 より,アクチュエータに粘性要素が存在しているためと 思われる.

\section{7. 結}

温度により棡性が変化する SMA 線を 1 対に構成する ことで，自己の剛性を調整し得るといった人間に似た特 性をむつアクチュエータが開発でき，その力学モデルが 示されたまた，伸張反射実験より，このアクチュエー
タが弾性のみでなく，粘性も含み，粘弾性要素であり， それ自身が安定な系であることがわかった，尚，SMA 自身が粘弾性の材料特性を示すことは，立石氏ら ${ }^{9,10)} に$ よって示されており，本アクチュエータの同様の性質は， この SMA 自身の特性を反映したものと思われる.

位置と剛性を独立に制御する方法が提案された，位置 についてはフィードバック制御を行い, 剛性はオープン で制御される.

このフィードバック制御は単純な比例制御で行なった が, SMA アクチュエータの特徵から安定な制御ができ

$$
\begin{array}{ll}
-\ldots-: & k=2.2 \text { [duty/rad] } \\
--: & 6.6 \\
- & 11
\end{array}
$$

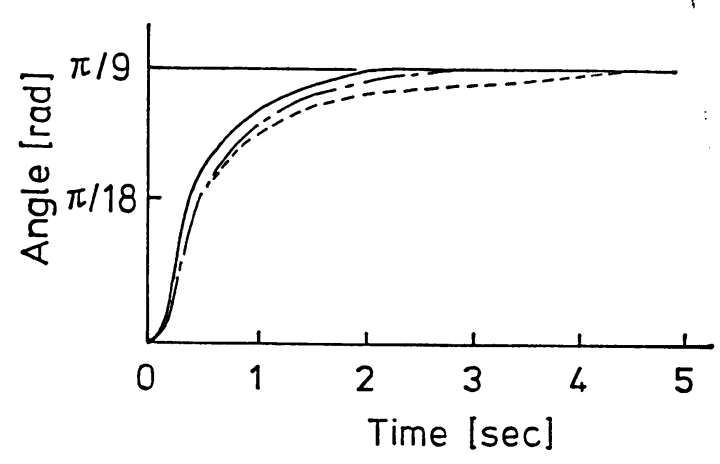

Fig. 17 Step response of the position control 
た. 本研究の SMA アクチュエータを用いることにより, ロボットのコンプライアントモーションの実現が可能と 思われる.

最後に，本研究を行らにあたり，古河電気工業（株） より SMA 線を提供していただいたことと, 服部報公会 より研究補助金の御援助を賜わりましたことに心から感 謝する次第である.

\section{参考 文 献}

1) Matthew, T. Masson, "Compliant Motion", Robot Motion, The MIT Press, pp.305-322, 1983

2) 花房秀郎, “メカニカルハンドとその制御”, 計測と制 御, Vol.18, No.1, pp. 30-36, 1979

3) Neville Hogan, "Mechanical Impedance Control in Assistive Devices and Manipulators", Robot Motion, The MIT Press, pp.361-371 1983.

4）舟久保熙康編，“形状記憶合金”産業図書, 1984
5）栗林勝利，“形状記憶合金を用いた位置制御”，システム と制御，Vol.27，No.9， pp.589-597，1983

6) 本間大, 三輪敬之, 井口信洋, “形状記憶効果を利用し たディジタルアクチニエータ”日本機械学会論文集（C 編), Vol.49, No.448, pp. 2163-2169.

7）広瀬茂男，生田幸士，梅谷陽二，“形状記憶合金アクチ ニエータの開発”, 日本ロポット学会誌, Vol.4, No.6, pp. 28-38, 1986.

8）橋本ら，“形状記憶合金アクチニエータとその二足歩行 ロボットへの応用”第 1 回日本ロボット学会学術講演会 予稿集, pp. 207-208, 1983

9）高橋恭彦，立石哲也，斉藤正克，鈴木堆一, “ NiTi 形状 記憶合金の振動特性に 関する研究”, 日本機械学会論文 集 (A 編) 51 巻, 462 号, pp. 483-487, 1985.

10）立石哲也，白崎芳夫，鈴木雄一, “ $\mathrm{NiTi}$ 形状記憶合金の 衝撃王縮特性に関する研究”, 日本機械学会論文集（A 編) 51 巻, 462 号, pp. 493-498, 1985.

11）梶山ら，“伸張反射に着目したヒトの上肢位置制御機構 の解析”, バイオメカニズム 4, 東京大学出版会, pp. 5968,1978

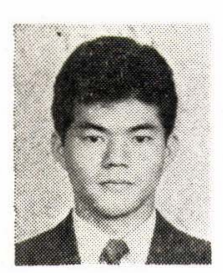

\section{佐川浩文 (Hirofumi SAGAWA)}

昭和 61 年電気通信大学大学院, 機械工 学専攻修士課程修了, 現在, 三菱電機株式 会社, 稲沢製作所, 開発部勤務.

(日本ロポット学会正会員)

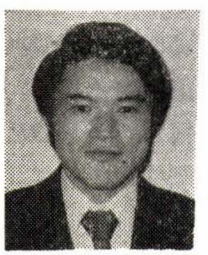

\section{橋本稔 (Minoru HASHIMOTO)}

昭和 55 年東京大学大学院, 金属材料学 専攻, 修士課程修士課程修了, 同 57 年同 大学博士課程中退, 同年より電気通信大学 短期大学部助手, 62 年同大電気通信部機槭 制御工学科助手, 60〜62 年の間, ペンシル バニア大学にてロポットの制御に関する研 究に従事. 昭和 58 年工学博士. (日本ロボット学会正会員)

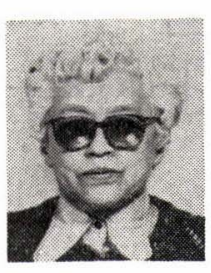

佐藤公子 (Kimiko SATŌ)

昭和 22 年, 津田熟専門学校, 物理化学 科卒業, 昭和 22 年より 43 年まで東京工 業大学金属工学科に勤務 43 年上り電気通 信大学, 短期大学部, 62年同大電気通信学 部機械制御工学科に所属.

昭和 37 年工学博士

（日本ロボット学会正会員）

\title{
Stiffness Control of Shape Memory Alloy Actuator* \\ Hirofumi SAGAWA** Minoru HASHIMOTO*** \\ Kimiko SATO***
}

\begin{abstract}
In the present paper we propose a control technique of stiffness for the actuator in which shape memory alloys (SMA's) are used. The actuator was made by a pair of SMA wires with rivalry. The wires are heated directly by an electric current. The static model of the actuator is suggested and then it is found from the model that the stiffness can be controlled by the sum of amounts of currents of the wires. The validity of the control method was verified by the experiment. A position control scheme with keeping command stiffness also will be proposed in this paper.
\end{abstract}

Key words: Shape Memory Alloy, Acutuator, Stiffness Control, Position Control, Duty Ratio

* Received March 31, 1987

** Mitsubishi Electric Co. LTD

*** University of Electro-Communications 